\title{
LEGAL INCONSISTENCY AND THE EMERGENCE OF STATES
}

\section{N. W. BARBER ${ }^{1}$}

Should contractions within legal orders always be regretted? Most of the time they are clearly undesirable. The conflicting demands that they make runs against the rule of law - they impair the capacity of the law to guide conduct, and, worse still, may sometimes compel individuals to choose a law to break. Normally, institutions within the legal order should strive to avoid creating contradictions and, where such contradictions exist, should work towards their elimination. Sometimes, though, there are countervailing benefits, especially in the area of constitutional law. Here, contradiction between legal rules may reflect political disagreement about the balance of power within the state or, even more profoundly, disagreement about where the boundaries of the state should be drawn. Allowing a legal contradiction to persist may permit those with profoundly different understandings of the constitution to work within the existing institutional structure. This may sometimes be a temporary fix, merely postponing a constitutional crisis to a future date, but sometimes the problem resolves itself: one side of the argument is a clear winner, and the legal order can adjust itself to reflect this victory. By delaying the resolution of the dispute, the legal contradiction may have helped avoid a constitutional crisis.

This chapter will begin by outlining a version of legal pluralism that turns on contradictions within legal orders. As this account of legal pluralism turns on the possibility of legal contradiction, and, indeed, argues that there is sometimes a utility to be found in these contradictions, the paper sits comfortably alongside Patrick Glenn's account of legal orders. ${ }^{2}$ It is not claimed that this is the only possible meaning that could be ascribed to legal pluralism, but it is an interpretation that fits with some of the older writings on pluralism and, more importantly, picks out a significant constitutional phenomenon that merits consideration. Having set out this

\footnotetext{
1 Some paragraphs of this paper draw heavily on N. W. Barber, 'Legal Pluralism and the European Union' (2006) 12 European Law Journal 306, and I am grateful to the editor of that journal for permission to make use of that article. Thanks are also due to Cora Chan, Ewan Smith, Lionel Smith, and Greg Weeks for their helpful comments on an earlier draft of this paper.

2 See especially, P. Glenn, Legal Traditions of the World $5^{\text {th }}$ ed. (Oxford: Oxford University Press, 2014), chapter 10.
} 
model, it will be argued pluralism can be identified within a number of emerging political orders, and is sometimes used to accommodate political disagreement about the boundaries of the state.

\section{A Model of Legal Pluralism}

Legal pluralism emerged as a collection of approaches to understanding legal orders during the 1970s and 1980s. ${ }^{3}$ There were two broad groups of ideas that marched under the pluralist banner. First, some writers developed a pluralist model through reflection on the ways in which different normative orders can interact. These accounts of pluralism started in the analysis of imperial legal systems, examining the ways these systems had accommodated, incorporated, and limited religious and local law. ${ }^{4}$ Other scholars challenged the divide between 'legal' and 'non-legal' rules by drawing attention to the totality of rules that govern people's lives: state law was not the only normative system that impacted on members of the state. ${ }^{5}$ For these scholars, legal pluralism embodied the recognition that people were governed by different normative systems, systems which the legal orders of states often tried to accommodate or shape in some way. The second strand of legal pluralism - and one which is more directly relevant to the focus of this book considered the potential for inconsistency, or contradiction, between rules, claiming that there can be contradictory 'legal mechanisms' applying to single factual situations. ${ }^{6}$ These two strands sometimes come together: on occasion, it is the

\footnotetext{
3 See generally, J. Griffiths, 'What is Legal Pluralism?' (1986) 24 Journal of Legal Pluralism 1 and D. J. Galligan, Law in Modern Society (Oxford: Oxford University Press, 2006), chapters 9 and 10.

4 For instance, M. B. Hooker, Legal Pluralism - An Introduction to Colonial and Neo-Colonial Laws (Oxford: Oxford University Press, 1975).

5 S. Moore, 'Law and Social Change: the Semi-Autonomous Social Field as an Appropriate Subject of Study' (1973) 7 Law and Society Review 719; Griffith, note 3 above, 38-39; see also E. Ehrlich, Fundamental Principles of the Sociology of Law, transl. W. L. Moll, (New York: Russell and Russell, 1936).

6 J. Vanderlinden, 'Le Pluralisme Juridique: Essai de Synthèse' in J. Gilissen, ed., Le Pluralisme Juridique (Brussels: Université de Bruxelles, 1971), 19. See also: S. Merry, 'Legal Pluralism' (1988) 22 Law and Society 869, 870; R. de Lange, 'Divergence, Fragmentation and Pluralism', in H. Petersen and H. Zahle, eds., Legal Polycentricity: Consequences of Pluralism in Law, (Aldershot: Dartmouth Publishing, 1994); A. Arnaud, 'Legal Pluralism and the Building of Europe' in the same volume; N. MacCormick, 'Juridical Pluralism and the Risk of Constitutional Conflict' in N. MacCormick, Questioning Sovereignty (Oxford: Oxford University Press, 1999).
} 
interaction of two normative systems that has generated the inconsistency in the rules that apply to individuals.

A significant challenge to the would-be pluralist is to show that their accounts of legal orders are distinctive. If it is the recognition that there can be interaction between different normative orders that is at the heart of pluralism, pluralism, as a distinct way of conceiving law, would appear unremarkable. Legal orders commonly recognise and even apply the rules of other systems, ${ }^{7}$ and even the staunchest of legal positivists would acknowledge that other normative systems can bear on an individual and can have a practical impact as great as, or greater than, law. ${ }^{8}$ Whilst the consequences of interaction between normative orders can be fascinating, ${ }^{9}$ the recognition that they do interact is unexceptional. Similarly, the assertion that rules can place contradictory demands on those they address would be very widely endorsed. There is very broad, perhaps even universal, acceptance that the rules of different normative orders can impose contradictory demands on individuals. And, with the exceptions of Hans Kelsen ${ }^{10}$ and, perhaps, Ronald Dworkin, ${ }^{11}$ most would recognise that it is possible that rules within a single normative order can conflict; indeed, normally, it is one of the core tasks of the judge to bring such conflicts to an end.

\footnotetext{
7 H. Kelsen, General Theory of Law and the State, transl. A. Wedberg, (Cambridge Mass.: Harvard University Press, 1945), 243-248.

8 Ibid., 24-28, discussing Ehrlich, note 5 above.

9 P. Glenn, The Cosmopolitan State (Oxford: Oxford University Press, 2013)

${ }^{10}$ Kelsen, note 7 above, 407-408; H. Kelsen, The Pure Theory of Law, transl. M. Knight (California: University of California Press, 1967), 205-208. Kelsen abandoned this claims, though he never fully explained the reasons for his change of mind: J. Harris, 'Kelsen and Normative Consistency' in R. Tur and W. Twining eds., Essays on Kelsen (Oxford: Oxford University Press, 1986), S. Munzer, 'Validity and Legal Conflicts' (1973) 82 Yale Law Journal 1140, 1164. I engage with Hans Kelsen's claim that legal rules cannot be set in contradiction in N. W. Barber, The Constitutional State (Oxford: Oxford University Press, 2010), chapter 9.

11 R. Dworkin, 'On Gaps in the Law', in P. Amselek and N. MacCormick eds., Controversies about Law's Ontology (Edinburgh: Edinburgh University Press, 1991), R. Dworkin, 'No Right Answer?' in P. M. S. Hacker and J. Raz, eds., Law, Morality and Society (Oxford: Oxford University Press, 1978); Munzer, note 10 above, 1156-1162. I engage with Ronald Dworkin's objection to pluralism in N. W. Barber, 'Legal Realism, Pluralism, and their Challengers' in U. Neegaard and R. Nielsen eds., European Legal Method - Towards a New European Legal Realism? (Copenhagen: DJOEF Publishing, 2013).
} 
Indeed, the challenge to those who want to talk of 'contradiction' or 'inconsistency' in the context of legal rules may be even more profound. Others in this volume debate the question, but the logical principle of contradiction is often taken to be confined only to propositions of fact; normative systems are commonly excluded from its reach. ${ }^{12}$ The factual claim that $A$ exists and $A$ does not exist violates the logical principle of non-contradiction; most people would think that one or other of these claims must be false. But on some understandings of morality, a person can find that they are subject to moral obligations that conflict; morality may require both action and inaction. ${ }^{13}$ More strongly still, law is an artificial normative structure, a structure within which legislatures and courts can craft and impose obligations. Even if it is the case that the principle of non-contradiction applies in systems of ethics it does not follow from this that it necessarily applies in systems of law. Indeed, one of the foremost advocates of deontic logic, G. A. von Wright expressly excluded legal systems from its reach. ${ }^{14}$ Though it may be desirable that rules within a legal order not contradict each other, this, according to von Wright, is not a logical truth about such orders. ${ }^{15}$ Legal systems are artificial normative structures, and, as such, are not constrained to comply with all the dictates of logic and the examples given in the remainder of this chapter will show how the institutions of law can, sometimes generate opposing rules. The challenge to those who talk of contradiction within and between legal orders is, then, to explain what this means in the context of law.

\footnotetext{
${ }^{12}$ See the discussion in J. Jørgensen, 'Imperatives and Logic' (1937-38) 7 Erkenntnis 288 and S. Coyle, 'The Possibility of Deontic Logic' (2002) 15 Ratio Juris 294.

13 P. Foot, 'Moral Realism and Moral Dilemma' (1983) 80 Journal of Philosophy 379. See also T. Nagel, 'The Fragmentation of Value' in T. Nagel, Mortal Questions (Cambridge: Cambridge University Press, 1979) and B. Williams, 'Ethical Consistency' in B. Williams, Problems of the Self (Cambridge: Cambridge University Press, 1973).

14 G. A. von Wright, 'Deontic Logic' (1999) 12 Ratio Juris 26, 32-33.

15 Note that a distinction can be drawn between a proposition about a norm (there is a rule you must do $\mathrm{x}$ ) and the obligation imposed by the norm (you must do $\mathrm{x}$ ). The logical principle of noncontradiction may well apply to propositions about norms (such a rule either does or does not exist). It is harder to see that it applies to the obligations imposed by the norm, as there may be other norms that require the opposite action.
} 
Bernard Williams tackled this problem by shifting normative statements into their descriptive equivalents, which might be termed compliance statements. ${ }^{16}$ So, the normative statement 'Albert must not kill Alberta' is transposed to 'Albert did not kill Alberta', which is contrary to the rule 'Albert must kill Alberta' transposed to 'Albert did kill Alberta.' This device allows us to talk of contradictory rules without assuming the logical conception of non-contradiction can be directly applied to normative statements. The transposition also makes clear that the contradiction between rules lies not in their inherent truth or falsity, but in their subjects' inability to fully comply with the rules: a claim that both had been fully complied with would necessarily be untrue. Whilst it is appropriate to judge assertions of the possibility of joint compliance as being true or false, it is not necessary to assume that the obligations themselves that generate these compliance statements are susceptible to attributions of truth-value. Consequently, the claim that contradiction can be found within and between legal orders is, or should be, less controversial than a general rejection of the logical principle of non-contradiction found in classical logic. ${ }^{17}$

On both of these grounds - the possibility of multiple normative orders and the potential for inconsistency within a normative order - legal pluralism faces the challenge that its central theses might prove to be trite: if its central claims are very widely endorsed, it might not be all that valuable as a distinct way to look at legal orders.

In earlier work, I have argued that contradiction between legal rules becomes particularly interesting when it is found at the foundational level of legal orders. Sometimes, this inconsistency concerns the hierarchy of sources of law within a system and, as a consequence of this, the system may lack an institution that is legally empowered to resolve the inconsistency. There are multiple, inconsistent, rules of recognition that give priority to rival sources of law, and there are rival institutions that purport to have the final say about the content of the legal order. Consequently,

16 B. Williams, 'Consistency and Realism' in B. Williams, Problems of the Self (Cambridge: Cambridge University Press, 1973) and H. L. A. Hart, 'Kelsen's Doctrine of the Unity of Law' in H. L. A. Hart, Essays in Jurisprudence and Philosophy (Oxford: Oxford University Press, 1983), 324-327.

17 I discuss the significance of the logical principle of non-contradiction for normative systems - and the complexities of Bernard Williams' notion of 'compliance statements' - at far greater length in N. W. Barber, The Constitutional State (Oxford: Oxford University Press, 2010) chapter 9. 
pluralist legal orders contain a risk, which need not be realised, of constitutional crisis; of officials being compelled to choose between their loyalties to different public institutions.

The claim that legal orders can exist with multiple, unranked, rules of recognition is controversial. The rule of recognition is a central part of Herbert Hart's account of law and - if it is to achieve the ends Hart set for it - such inconsistency must be rare. For Hart, the rule of recognition served to unite the rules of a legal system, providing a test by which other rules could be shown to form part of the legal order. ${ }^{18}$ Each legal system therefore possessed its own unique rule of recognition, ${ }^{19}$ and all the rules that could be identified through the application of the rule of recognition constituted a single legal system. The rule of recognition also provided an answer to the question of the continuity of legal systems, the means by which we can show that two different sets of legal rules are manifestations of the same legal system at different points in time. ${ }^{20}$ These sets of rules are aspects of a continuing legal system when the changes that occurred between the two sets of rules occurred in conformity to the rules of change identified by the rule of recognition. The existence of a single rule of recognition was necessary for the success of Hart's answer to these central jurisprudential questions: it sought to explain how the boundaries of a momentary legal order could be drawn, and how a series of momentary legal orders can be identified as constituting a single legal order stretched over time.

Hart was not unaware of the problems that disputes over the rule of recognition caused his theory. In the context of revolutions and invasion he acknowledged the possibility of such a state of affairs: it was conceivable that two rival rules of recognition might operate within a territory, and yet only one legal

\footnotetext{
${ }^{18}$ H. L. A. Hart, The Concept of Law, $2^{\text {nd }}$ ed., (Oxford: Oxford University Press, 1994), 113-115.

19 H. L. A. Hart, 'Legal Duty and Obligation' in H. L. A. Hart, Essays on Bentham (Oxford: Oxford University Press, 1982), 155, ftn. 77. See also: N. MacCormick, 'The Concept of Law and 'The Concept of Law” (1994) 14 Oxford Journal of Legal Studies 1, 13-15; N. MacCormick, 'A Very British Revolution' in N. MacCormick, Questioning Sovereignty (Oxford: Oxford University Press, 1999).

20 Though Hart does not make this point explicitly: see J. Finnis, 'Revolutions and Continuity of Law' in A. Simpson, ed., Oxford Essays in Jurisprudence (Second Series) (Oxford: Oxford University Press, 1973), 54-57.
} 
system was in operation. ${ }^{21}$ This was, though, a 'substandard, abnormal case containing with it the threat that the legal system will dissolve. ${ }^{22}$ For Hart, such cases needed to be marginalised because if they were a common occurrence they would throw doubt on the success of the rule of recognition as the answer to the identity questions posed earlier.

Hart's account of a legal system was non-pluralist, in the sense invoked in this chapter. The central case of a legal system contained a single rule of recognition, directing the law-applying institutions to the sources of law. Whilst Hart envisaged the possibility of pluralist systems, where there were inconsistent rules of recognition, he understood these as deviant cases. They constituted legal systems because of their similarity to the central case he presented, and were inherently unstable. If pluralist systems are more common, or more lasting, than Hart believed, the centrality of his non-pluralist account would have to be reassessed. Reflection on these, and other, problems with the rule of recognition has led Hart's students away from the rule of recognition as the answer to the questions of the identity of legal systems: both Joseph Raz and John Finnis have advanced more flexible understandings of legal systems, which moved away from Hart's rule-focused account and have made room for the possibility of pluralist legal orders. ${ }^{23}$

\section{EXAMPLES OF PLURALIST LEGAL ORDERS}

There are a number of reasons why it is valuable to identify pluralist legal orders. First, and building on arguments made in the previous paragraphs, such an exercise may help us answer general questions about the nature of law, questions of the type Hart sought to answer. If it can be shown that pluralist legal orders are comparatively common and, at least sometimes, are stable, it suggests that the general

\footnotetext{
21 As in Rhodesia: G. Marshall, Constitutional Theory (Oxford: Oxford University Press, 1971), 64 72; J. Eekelaar, 'Splitting the Grundnorm' (1967) 30 Modern Law Review 156.

22 Hart, note 18 above, 123.

${ }^{23}$ Finnis, note 20 above; J. Raz, 'The Identity of Legal Systems' in J. Raz, The Authority of Law, (Oxford: Oxford University Press, 1979).
} 
account of law provided by Hart requires modification. ${ }^{24}$ Second, the exercise may be of interest to those who study constitutions and the operation of states. A pluralist legal order may provide a distinctive form of constitutional ordering that might mitigate the corrosiveness of some profound political disagreements. Thirdly, it may prove of interest to those interested in the particular legal orders examined: comparing these systems with others experiences similar challenges may illuminate shared and significant features. The present chapter focuses on the second of these three tasks.

Three examples of potentially pluralist legal orders, or groups of legal orders, will be given in this section: the legal orders of the European Union, the legal order of Australia before 1986, and the current legal order of Hong Kong. As we shall see, in all of these cases the legal inconsistency that is characteristic of legal pluralism has, at its root, a political disagreement over the boundaries of the state. Here, legal pluralism is a consequence of the disputed relationship between a region - the Member States, Australia, and Hong Kong - and a larger constitutional entity - a putative European state, the British Empire, and China. This political disagreement then entails disagreement over the authority of the institutions of that larger entity over the region.

\section{(i) The European Legal Order}

I have discussed the implications of legal pluralism for Europe's legal orders at length elsewhere, but, in brief, the interaction of the Court of Justice of the European Union and some national supreme courts has created the possibility that pluralist legal orders may emerge at both the European and national levels.

The Court of Justice of the European Union makes three, interconnected, claims of supremacy. ${ }^{25}$ First, that the Court of Justice is entitled to definitively

\footnotetext{
24 I explore the jurisprudential implications of pluralism at far greater length in Barber, note 17 above, chapters 9 and 10 .

25 K. Alter, Establishing the Supremacy of European Law (Oxford: Oxford University Press, 2001), chapter 1; J. Weiler, 'The Autonomy of the Community Legal Order' in J. Weiler, The Constitution of Europe (Cambridge: Cambridge University Press, 1999).
} 
answer all questions of European Law. ${ }^{26}$ Secondly, that the Court of Justice is entitled to determine what constitutes an issue of European Law. ${ }^{27}$ Thirdly, that European Law has supremacy over all conflicting rules of national law. ${ }^{28}$ Set against this, many national constitutional courts have adopted a very different view of the force and nature of European law. Perhaps the most widely discussed set of judgments is found in the German legal system. ${ }^{29}$ In Solange $I^{30}$ the German Constitutional Court rejected the supremacy of European Law: rules of Community Law that conflicted with fundamental constitutional rights would not be applied in the German order. This was a challenge to the third of the three assertions of supremacy. In the Maastricht ${ }^{31}$ decision, the Court rejected the Court of Justice's claim to have the final say as to the meaning and scope of European Law. The German Court stated that it would not accept surprising readings of the Treaty that had the effect of extending the Union's powers. ${ }^{32}$ The recent decision on the Lisbon Treaty follows this jurisprudence: European law takes effect through and because of the German Constitution, and that Constitution limits what can be done in the name of European Law. ${ }^{33}$ These two accounts of the force of European law present us with a pair of inconsistent rules.

First, there is a pair of rules that ascribe precedence to different sources of law. According to the German Constitutional Court the German Constitution is the highest

\footnotetext{
26 Art. 234 (formally Art. 177)

27 J. Weiler, 'The Transformation of Europe' in J. Weiler, The Constitution of Europe (Cambridge: Cambridge University Press, 1999), 21. Case 314/85, Foto-Frost v. Hauptzollamt Lübeck-Ost [1987] ECR 4199.

28 Case 6/64 Costa v. ENEL [1964] ECR 585

29 For recent tensions produced by the European Arrest Warrant, see M. Fichera, 'The European Arrest Warrant and the Sovereign State: A Marriage of Convenience?' (2009) 15 European Law Journal 70.

30 Internationale HandelsgesellschaftmbH v. Einfuhr-und Vorratsstelle für Getreide und Futtermittel, [1974] CMLR 540

31 Brunner v. The European Treaty [1994] CMLR 57. See M. Zuleeg, 'The European Constitution Under Constitutional Constraints: The German Scenario’ (1997) 22 European Law Review 19 for energetic criticism of the decision, and M. Kumm, 'Who is the Final Arbiter of Constitutionality in Europe?’ (1999) 36 Common Market Law Review 351.

32 Brunner, note 31 above, paragraphs 33, 48-49.

33 See C. Wohlfahrt, 'The Lisbon Case: A Critical Summary’ (2009) 10 German Law Journal 1277.
} 
source of law within Germany. European Law takes effect through the German Constitution, and, consequently, can be constrained by constitutional rules. This supremacy doctrine is presented as implicit within the framework of the German Constitution. In contrast, the Court of Justice regards European Law as the highest source of law within the European Union, which, of course, encompasses Germany. This supremacy doctrine is presented as a consequence of the signing of the Treaties establishing the Union, and does not depend on the validation of the German Constitution. Each supremacy claim contains an implicit negation of the other. In both cases these rules are presented as duties resting on the courts: each court claims that it is compelled to give precedence to the different sources of law.

Secondly, there is a pair of inconsistent rules relating to the hierarchy of courts within Germany. Again, this inconsistency takes the form of a combination of duties and powers. In some situations both courts regard themselves as under a duty to make the final determination about the content of law in Germany. The rules are asymmetrical: whilst the German Constitutional Court regards itself as under a duty to have the final say about the content of all the laws operative in Germany, the Court of Justice only claims to be obliged to have the final say about those laws with a European element that are operative in Germany. These duties could be acquitted by merely endorsing the decision of the other body - but the duties prohibit the acceptance of the other body's claim to authority. A simple pair of duties to express a view about the law within a territory would not be inconsistent - what makes these rival claims to adjudicative supremacy inconsistent is their assertion of finality: a duty to state authoritatively for those affected by the law what the law requires of them. Adjudicative supremacy is a duty coupled with a power to bind people, courts and other institutions. It is these powers, inextricably mixed with the duties, which create the potential for inconsistency. This inconsistency need not be realised - perhaps the rival bodies will agree - but there is the unavoidable potential for actual inconsistency; that individuals will be placed in a position where they cannot fully comply with the directives produced by each court.

This type of conflict can generate a form of legal pluralism that is both novel and interesting. It can lead to multiple unranked rules of recognition, each according priority to a different source of law and different adjudicative institution. The 
jurisprudence of the German Constitutional Court is far from unique, and other national courts have adopted similar positions. ${ }^{34}$ This conflict - between the Court of Justice and national constitutional courts - has the potential to create a form of legal pluralism at two levels.

First, the European legal order may, itself, be pluralist. The European legal order consists of courts at the European level and, also, courts at the national level. If we take the courts of Europe to comprise parts of a single legal order, this legal order will include multiple rules of recognition. Different judges in different courts would have different views about the hierarchy of legal sources within the Union - even if they accepted that this disagreement existed within a legal order.

Secondly, the legal orders of the Member State are, or, more likely, may become, pluralist. Over time, judges within the Member States may disagree over the rule of recognition - with some judges following their national constitutional courts and others following the Court of Justice. It is possible that this disagreement might arise in a time of crisis, with all the parties compelled to find a solution quickly, ${ }^{35}$ but it might also arise over a long period of time, without any single moment of conflict. Indeed, it is possible that such a situation could be stable, with the judges agreeing on the substantive law that needs to be applied to cases before them, but disagreeing on whether this is because their national constitution requires it, or because of their country's membership of the European Union.

(ii) The Pre-1986 Australian Legal Order

Within Europe, legal inconsistency is the product of political disagreement; the inconsistencies in law are, in part, motivated by rival visions of the future of the Union. Australia may provide an example of legal inconsistency arising as a result of

\footnotetext{
${ }^{34}$ See, amongst others: Italy: Frontini v Ministero delle Finanze [1974] 2 CMLR 372; France: Nicolo [1990] 1 CMLR 173; United Kingdom: $R$ (HS2 Action Alliance Ltd) v Secretary of State for Transport [2014] UKSC 3. See also W. Sadurski, 'Solange, Chapter 3: Constitutional Courts in Central Europe Democracy - European Union' (2008) 14 European Law Journal 1.

35 As with Rhodesia, see note 21 above.
} 
a contrasting process, where a developing political consensus triggered a shift in the law.

The Australian legal order started life as an off-shoot of the imperial legal order, with the Imperial Parliament - Westminster - being the highest law-making body in the system, and the Privy Council standing as the final court of appeal. As Australia's distinct constitutional identity emerged during the twentieth century, this legal position appeared increasingly anachronistic. Well before the Australia Acts, passed in 1986 by the Australian and United Kingdom Parliaments, ${ }^{36}$ settled the issue, the fundamental base of Australian law was disputable. Even before the formal severance of Australia's link with the Imperial legal order, Australian judges had started to create constitutional space between Australia and the old imperial institutions.

First, the role of the imperial courts was steadily reduced. ${ }^{37}$ Initially, this was as a result of legislation - in 1968 and 1975 the Australian Parliament limited the range of cases in which a litigant could appeal to the Privy Council ${ }^{38}$ - but these legislative limitations were supported and reinforced by the judges. The High Court confirmed that the Australian Parliament did, indeed, possess the capacity to constrict access to the imperial court, ${ }^{39}$ and it was the High Court, rather than the Parliament, that finally ended the capacity of the Australian states to appeal through it to the Privy Council. ${ }^{40}$ As the possibility of appeal to the Privy Council was steadily restricted, the High Court also sought to limit the significance of the rulings of that body. In Viro $v$ The Queen it was no longer bound by decisions of the Privy Council, ${ }^{41}$ and a

\footnotetext{
36 Australia Act 1986 (Cth); Australia Act 1986 (UK)

37 G. Williams, S. Brennan, A. Lynch, Australian Constitutional Law and Theory (6 ${ }^{\text {th }}$ ed.) (Sydney: Federation Press, 2014), 118-121.

38 Privy Council (Limitation of Appeals) Act 1968 (Cth); Privy Council (Appeals from the High Court) Act 1975 (Cth).

39 Attorney-General (Cth) v T\& G Mutual Life Society Ltd (1978) CLR 161.

${ }^{40}$ Kirmani $v$ Captain Cook Cruises Pty Ltd (No. 2) (1985) 159 CLR 461. Though the capacity of the State courts to allow appeals remained until 1986: Southern Centre of Theosophy Inc v South Australia (1979) 145 CLR 246.

41 Viro v The Queen (1978) 141 CLR 88.
} 
majority of the judges in that case asserted that state courts should treat decisions of the High Court as taking precedence over decisions of the imperial body. For a time, then, the High Court and the Privy Council both presented themselves as the apex court within the Australian system. A pair of inconsistent rules existed in the Australian legal order. The first identified the High Court as the final court of appeal, and imposed a duty on others within the Australian system to accept its decisions as taking precedence over the decisions of other courts. The second identified the Privy Council as the final court of appeal, and, similarly, imposed a duty on others within the system to accept its rulings, and accord them precedence over the decisions of other judicial bodies.

Secondly, alongside the marginalisation of the Privy Council, a number of Australian judges indicated that they would no longer accept the authority of the Westminster Parliament over Australia. ${ }^{42}$ Justice Murphy, in Bistricic v Rokov, argued that the United Kingdom Parliament had lost the power to pass statutes that were effective in the Australian legal order in 1901 after the enactment of Commonwealth of Australia Constitution Act 1900 (Imp). ${ }^{43}$ According to Murphy, the constitutional basis of the Australian system was the acceptance by the Australian people of this statute, rather than its enactment by Westminster; Westminster's lawmaking power over Australia had expired. In a later case Justice Deane expressed a similar view, albeit in more cautious language, indicating that, in future, the judges might endorse the view that Australia was a sovereign state, and, like Murphy, identifying the Australian people as the source of its constitutional authority. ${ }^{44}$ These opinions were far from uncontroversial, and as late as 1979 there were judges who were prepared to argue that Westminster retained a power to legislate for Australia. ${ }^{45}$ Consequently, in the period before the 1986 statutes, there was both explicit and deep

\footnotetext{
42 P. Oliver, The Constitution of Independence: The Development of Constitutional Theory in Australia, Canada and New Zealand (Oxford: Oxford University Press, 2005), 233-239.

${ }^{43}$ Bistricic v Rokov (1976) 135 CLR 552, 565-7. See also Robinson v Western Australia Museum (1978) 138 CLR 283.

${ }^{44}$ Kirmani v. Captain Cook Cruises Pty Ltd (No.1) (1985) 159 CLR 351, 442.

45 See Stephen J in China Ocean Shipping Co. v South Australia (1979) 145 CLR 172.
} 
disagreement about the basis of Australian law. ${ }^{46}$ This inconsistency between rival rules of recognition is even starker than that relating to courts, discussed in the previous paragraph. On the one hand, some judges identified the Westminster Parliament as the highest source of law in the Australian system. If Westminster chose to legislate for Australia, the Australian judges would be under a duty to apply these laws - no matter with what Australian law they conflicted. On the other hand, some judges regarded Westminster as standing outside of the Australian legal order. If Westminster chose to legislate for Australia this legislation would be ineffective Australian judges lacked the power to give it legal force and, indeed, under the Australian system, would be under an obligation apply the Australian law on the topic.

The inconsistencies relating to Australia's highest court and to its highest lawmaking body did not generate practical problems for litigants. Whilst the disagreements were profound, they did not affect the substantive, lower-level, laws that applied to individuals. The costs of the disagreement were potential rather than actual: these inconsistencies could have generated a constitutional crisis but, in the event, did not. Weighing against these risks, though, were benefits: the inconsistent rules stood as a warning, as an opportunity, and as threads that could later be woven into the constitutional story of an independent Australia. As warnings, these inconsistencies raised the potential costs for the Westminster Parliament in the highly unlikely - event that it might be tempted to legislate for Australia. There was a chance that such legislation would be ignored by the Australian courts and - as in the Rhodesian incident ${ }^{47}$ some twenty years earlier - the attempt to exercise the remnants of imperial power would lead to the extinction of that power. As an opportunity, the inconsistencies indicated that a portion, at least, of the judiciary would be willing to support Australian constitutional independence, even without the consent of the Westminster Parliament. The eventual mechanism used to secure independence legislation enacted in both the Australian and Westminster Parliaments simultaneously - was effective, but was, perhaps, not the only way in which this end

\footnotetext{
46 See A. Dillon, 'A Turtle By Any Other Name: The Legal Basis of the Australian Constitution' (2001) 29 Federal Law Review 241.

47 See note 21 above.
} 
could have been achieved. ${ }^{48}$ Finally, these inconsistent rules form part of the ideology that now animates the Australian constitution. When, after 1986, in Leeth the Australian High Court identified the Australian people as the source of the constitutional order, the judges were building on the ideas expressed in these earlier decisions. $^{49}$

(iii) The Contemporary Hong Kong Legal Order

In Australia the rise of legal inconsistency tracked a developing political consensus about the appropriateness of Australian constitutional autonomy: an emerging consensus shared by Australia and Westminster. In Hong Kong, in contrast, it is arguable that a form of pluralism has emerged because of a lack of consensus: uncertainty about Hong Kong's political relationship with China has been reflected in legal uncertainty over the basis of Hong Kong's legal order. Whilst there is agreement within Hong Kong that the historic origin of the Basic Law - Hong Kong's constitution - is found in the Chinese Constitution, ${ }^{50}$ there is uncertainty over the ongoing constitutional status of these instruments and their relationship. On one understanding, the Basic Law is contained within the Chinese Constitution; empowered by it, and subject to its provisions and institutions. The Chinese Constitution, on this account, is, ultimately, the highest source of law in Hong Kong. On an alternative understanding, the Basic Law is autonomous from the Chinese Constitution and it is the Basic Law, rather than the Chinese Constitution, that is the highest legal source within the territory of Hong Kong. If this alternative interpretation of the relationship between China and Hong Kong were adopted, the power of Mainland institutions over Hong Kong - and the import of the Chinese Constitution more generally - would be mediated through, and constrained by, the Basic Law.

\footnotetext{
48 Compare the experience of Ireland: K. Wheare, The Constitutional Structure of the Commonwealth (Oxford: Oxford University Press, 1960), 90-92. Dillon, note 46 above, 262-264.

49 (1992) 174 CLR 455. See also Nationwide News Pty Ltd v Wills (1992) 177 CLR 1. See Dillion, note 46 above, 246-253 for a sceptical consideration of the claims about popular sovereignty.

50 See Constitution of the People's Republic of China, Article 31.
} 
In one of the first cases in Hong Kong decided after the return of the island to China, Ma Wai-kwan, ${ }^{51}$ the Hong Kong Court of Appeal considered the continuing applicability of common law rules to Hong Kong. It decided that these rules remained part of that legal order, but only because the Basic Law incorporated them into the system. The foundation of the legal order had shifted from English law $^{52}$ to the Basic Law, which was, itself, grounded in the Chinese constitutional order: even though the vast bulk of the laws of Hong Kong remained constant, their constitutional foundation had changed. Albert Chen described this as amounting to a replacement of the grundnorm: ${ }^{53}$ the changing loyalties of the judges, motivated by the actions of the British and Chinese states, altered the fundamental rule of the Hong Kong legal order.

Ma Wai-kwan provided an account of the Hong Kong system that presented it as a subset of the Chinese constitutional order. If this were the case, the Chinese legislature, the National People's Congress, ${ }^{54}$ would enjoy the same capacity to legislate over Hong Kong that it possessed over the rest of China; a capacity unfettered by any form of judicial control. ${ }^{55}$ Under Ma Wai-kwan's model of the new constitutional order, Hong Kong had fully reunited with China, with the highest Chinese institutions accorded the same constitutional status they possessed within the rest of the Chinese system. In $\mathrm{Ng} \mathrm{Ka}$ - Ling, ${ }^{56}$ decided shortly after, the judges of the Court of Final Appeal took a different view. They presented Hong Kong's Basic Law as constraining the capacity of the Mainland's institutions to act within Hong Kong's constitutional order: Hong Kong's courts could review legislation of the National

\footnotetext{
51 [1997] 2 HKC 315.
}

52 The pre-1997 Hong Kong legal order rested on the exercise of a prerogative power: see A. Chen, 'The Interpretation of the Basic Law: Common Law and Mainland Chinese Perspectives' (2000) 30 Hong Kong Law Journal 380, 417-420.

${ }^{53}$ Ibid., 418.

54 It is worth noting that the National People's Congress is of limited effectiveness: it consists of about 3000 representatives who meet for about 10 days a year, and is controlled by the Chinese Communist Party. See Q. Zhang, The Constitution of China (Hart: Oxford, 2012), chapter 4.

55 Ibid., 95-96.

${ }^{56} \mathrm{Ng}$ Ka-Ling \& Others v Director of Immigration [1999] 1 H.K.L.R.D. 315 
People's Congress and the interpretive decisions of the Standing Committee that extended to Hong Kong. Where those decisions went against the Basic Law the Hong Kong courts could find them invalid or ineffective. This ruling proved to be the highwater mark of judicial separatism in Hong Kong. Following pressure from the Mainland, the Court glossed its decision, making clear that decisions of the Standing Committee of the National People's Congress bound the courts, ${ }^{57}$ and in Lau Kong Yung, ${ }^{58}$ decided later that year, the Court revisited the question of the relationship between the legal institutions of Hong Kong and those of the Mainland. It accepted that the Standing Committee of the National People's Congress had the power to issue binding interpretations of the Basic Law - even if there had been no judicial request for a ruling by that body. However, the case left open the question of whether this power was grounded in a provision of the Basic Law ${ }^{59}$ or in the Chinese Constitution $^{60}-$ as each instrument included such an interpretative power, the Hong Kong Court probably saw no need to choose between them. Lau Kong Yung consequently steers a middle course between Mai Wai-kwan and $\mathrm{Ng} \mathrm{Ka-Ling:} \mathrm{the}$ question of the fundamental basis of Hong Kong law is left open, and the possibility remains that a future court could hold that the Standing Committee's jurisdiction is confined within the bounds set by the Basic Law, as determined by Hong Kong institutions.

The power asserted in the first $\mathrm{Ng} \mathrm{Ka-Ling} \mathrm{decision} \mathrm{has} \mathrm{never} \mathrm{been} \mathrm{invoked}$ by the Hong Kong courts. ${ }^{61}$ If the National People's Congress's power to amend the Basic Law is limited by the Basic Law, ${ }^{62}$ it could be argued that the case places the

\footnotetext{
57 Ng Ka-Ling \& Others $v$ Director of Immigration [1999] 1 H.K.L.R.D. 577. See A. Chen, 'The Rule of Law Under 'One Country Two Systems' The Case of Hong Kong 1997-2010' (2011) 6 National Taiwan University Law Review 269, 271-276.

58 Lau Kong Yung v Director of Immigration [1999] 3 H.K.L.R.D. 778

59 Article 158 of the Basic Law.

${ }^{60}$ Article 67 of the Chinese Constitution.

${ }^{61}$ Though see HKSAR v Ng Kung Siu [1999] 1 H.K.L.R.D. 783 in which the Court of Final Appeal did review a decision of the Standing Committee to insert a Chinese law on flag desecration into the Basic Law, but, in the event, found it compatible with the Basic Law.

62 Article 159 of the Basic Law precludes amendments that 'contravene the established basic policies of the People's Republic of China regarding Hong Kong'.
} 
Basic Law above the Chinese Constitution in the context of the Hong Kong system: Hong Kong judges will only recognise as effective those amendments that are permitted by the Basic Law, after all, on this account, it is the Basic Law and not the Chinese Constitution that empowers the National People's Congress to act in Hong Kong. It is safe to assume that were this question put to the Standing Committee of the National People's Congress, this institution would side with the account of Hong Kong's legal order given in Ma Wai-kwan and reject that articulated in the original $\mathrm{Ng}$ Ka-Ling ruling.

Like the Australian cases, discussed above, the decision in $\mathrm{Ng} \mathrm{Ka-Ling} \mathrm{creates}$ ambiguity over the fundamental base of the Hong Kong order, an ambiguity that persists after Lau Kong Yung - and it is, perhaps, significant that one of the judges in $N g$ Ka-Ling was Sir Anthony Mason who had sat on a number of the key Australian cases discussed earlier. ${ }^{63}$ As with the pre-1986 Australian dicta, the judgment in $\mathrm{Ng}$ Ka-Ling should be seen as one that creates constitutional space rather than as an assertion of a power that the courts can utilise: as a matter of raw politics, it is hard, in present circumstances, to imagine a Hong Kong judge declaring a decision of the National People's Congress contrary to Hong Kong law. But the decision does create the possibility that, at some point in the future, Hong Kong's judges could use $\mathrm{Ng} \mathrm{Ka}$ Ling to distance Hong Kong's legal order from that of the Mainland. There is the potential that - in changed times - Hong Kong's courts could set aside attempts by China's institutions to determine the laws of Hong Kong - a potential that might, in itself, help restrain Beijing. And if there were a political will in Hong Kong to push towards constitutional independence, the Hong Kong courts, like their Australian cousins, would have introduced the flexibility into the constitutional order needed to accommodate these aspirations.

\section{CONCLUSION}

Ordinarily, inconsistency in law is a bad thing. Lon Fuller rightly claimed that the presence of inconsistent rules amounts to a standing criticism of the order that

\footnotetext{
${ }^{63}$ Mason sat in Bistricic and Kirmani, and the post-1986 case of Leeth.
} 
contains them, a blow against the rule of law. ${ }^{64}$ But there may be some situations where inconsistency is desirable; a way through which the law can accommodate competing political visions that are, on the surface, irreconcilable. This may be especially useful when the competing visions relate to the identity of the state. The three examples given in the last section show the different ways in which this model of legal pluralism may moderate the political problems raised by the emergence of new states by accommodating different visions of their constitutional futures.

In Europe, legal pluralism permits the Member States and the European Union to present themselves as states. ${ }^{65}$ The legal model favoured by the Court of Justice of the European Union is very similar to that of a federal state, with the treaties effectively dividing power between the European and national levels, and the Court of Justice acting as constitutional court, resolving questions over this division. The model favoured by many national courts, in contrast, is confederal, with the European Union enjoying a limited law-making power that is dependent on the agreement of, and support of, Member States.

In Australia, the shifting judicial view of the basis of the authority of the Australian constitutional tracked a shifting political consensus about Australia's relationship with the United Kingdom. Whilst the judges lacked the legal power to effect a split from the old imperial legal order - their legal authority was grounded in that system - their constitutional position enabled them to open the possibility of a split. The inconsistent rules within the legal order reflected the older view of the Australian legal order within the imperial system and a newer view, which accorded the Australian system autonomy. Had the United Kingdom resisted calls for Australian autonomy, or if it had sought to start legislating for the territory, this new view would have allowed the courts to counter such actions, presenting the possibility that the judges would side with Australian institutions against the old imperial power.

Unlike Australia, there is no clear political consensus about the future of Hong Kong. The legal relationship between Hong Kong and China resembles, in some

\footnotetext{
${ }^{64}$ L. Fuller, The Morality of Law, rev. ed., (New Haven: Yale University Press, 1969), 65-70.

${ }^{65}$ See Barber, note 17 above, chapter 10.
} 
respects, the old legal relationship between Australia and the United Kingdom, but the political connection between the two is far tighter. And whilst the gradual constitutional separation of Australia and the United Kingdom was both anticipated and broadly accepted, Hong Kong's constitutional future is far less clear. The inconsistency in Hong Kong's legal order stands as a potential vision of the future of that territory, a future in which Hong Kong would enjoy practically full constitutional independence from China, an autonomy that would virtually amount to statehood. Whilst such a development is politically inconceivable today, it may become viable in the future - or, perhaps, presenting it as a possibility may help guard the more limited autonomy Hong Kong presently enjoys.

There are, then, at least three reasons why legal inconsistency of this type may sometimes be valuable.

First, this sort of inconsistency described here may amount to a political compromise; a tacit agreement to disagree. ${ }^{66}$ It allows supporters of European supremacy and supporters of national supremacy to both claim victory; conversely, and perhaps even more importantly, it avoids either constituency having to admit defeat. These inconsistent laws need not demand inconsistent action; the constitutional dilemma can remain unresolved, provided that each side exercises restraint. The emergence of pluralist legal systems with the European Union may provide a desirable compromise between the old models of sovereignty and constitutional supremacy, and the new claims to supremacy made by Europe. Similarly, in Australia the relationship between Australian law and imperial law was widely debated, whilst a split was inevitable the speed with which this occurred was debated: the judicial disagreement over the fundamental base of the Australian legal order tracked this political debate. Whilst the political debates in the European and Australian examples turn on finality, and cannot reach a compromise through the adoption of an agreed middle course, the pluralist model provides a compromise framework within which these inconsistent claims can co-exist in law. Provided that

\footnotetext{
${ }^{66}$ C. Richmond, 'Preserving the Identity Crisis: Autonomy, System and Sovereignty in European Law' (1997) 16 Law and Philosophy 377; M. Maduro, 'Europe and the Constitution: What If This Is As Good As It Gets?' in J. Weiler and M. Wind, eds., European Constitutionalism Beyond The State, (Cambridge: Cambridge University Press, 2003). See also N. Krisch, 'The Open Architecture of European Human Rights Law' (2008) 71 Modern Law Review 183.
} 
the practical conflict within this model remains potential, and actual disputes are avoided, this can provide a stable, even a long-lasting, form of settlement. The advantage of such a settlement is that it avoids unnecessary and potentially destructive conflict, and allows the protagonists to work together on beneficial projects where agreement exists. ${ }^{67}$

Secondly, the pluralist model can create flexibility in the law that may facilitate the emergence of a new constitutional settlement. The inconsistency in the European legal order may prove long-lasting, but it could be, over time, that the federal model wins out. The existence of inconsistency presents this model as a possibility within the constitutional order, an option that the system can move towards. This facilitative role for inconsistency can be seen even more clearly in the Australian example, where the beginnings of constitutional autonomy pre-date the legislative provisions that brought about this end.

Thirdly, these inconsistent rules, embodying competing supremacy claims, could provide a form of 'constitutional self-defence'. ${ }^{68}$ A rule of constitutional selfdefence empowers an institution to protect itself against other constitutional bodies. For instance, legislatures are given judicial powers in the area of privilege to stop the encroachment of the courts, and judges often run the administrative side of the court process. Sometimes these measures are more aggressive, giving one institution a weapon it can use against another: for instance, giving one legislature the power to strike down the acts of another legislative body. Competing claims to supremacy arm national and European courts with weapons that may help ensure mutual respect and restraint. If the potential conflicts caused by inconsistent rules of recognition were

\footnotetext{
${ }^{67}$ Compare the long-standing debate in English constitutional law over which institution has the final say over the extent of parliamentary privilege: C. Wittke, The History of English Parliamentary Privilege (Ohio: Ohio University Press, 1921), J. Chaftez, Democracy's Privileged Few (New Haven: Yale University Press, 2007), chapter 3, and J. Dean, Hatred, Ridicule or Contempt (London: Constable, 1953), chapter 19.
}

${ }^{68}$ See N. W. Barber 'Self-Defence for Institutions' (2013) 72 Cambridge Law Journal 558 and N. W. Barber and A. L. Young, 'Prospective Henry VIII Clauses and their Implications for Sovereignty' (2003) Public Law 112. Similar points are discussed by Weiler and by Walker: see J. Weiler, 'The Reformation of European Constitutionalism' (1997) 35 Journal of Common Market Studies 97 and N. Walker, 'Sovereignty and Differentiated Integration in the European Union' (1998) 4 European Law Journal 355, 375-379. 
realised, with inconsistent rules addressed to individuals, all sides in the dispute would pay a price. Further, in the event of actual conflict, one side will, probably, emerge from the crisis as a victor: whilst it is unclear who will win, each side has an interest in avoiding the contest. The risks of actual conflict provide incentives on each party to strive towards harmonious interpretation of the law. It encourages the Court of Justice to interpret European law in a manner that will be palatable to national courts, ${ }^{69}$ and, at the same time, discourages national courts from blindly insisting on the primacy of national rules. In short, the competing supremacy claims may serve to create an atmosphere of co-operation between the courts, where each side has an incentive to strive to respect the position and tradition of the other. Similarly, in Hong Kong the possibility that the Hong Kong courts might reject a purported ruling of the Standing Committee of the National People's Congress on the interpretation of the Basic Law might encourage this body to exercise restraint when engaging with Hong Kong.

\footnotetext{
69 As evidence of this see, perhaps, J. Coppel and A. O'Neill, 'The European Court of Justice: Taking Rights Seriously?' (1992) 12 Legal Studies 227, though their claims are challenged in J. Weiler and N. Lockhart, “Taking Rights Seriously’ Seriously: The European Court and its Fundamental Rights Jurisprudence' (1995) 32 Common Market Law Review 51 and 579.
} 